\title{
CSALÁD ÉS/VAGY KARRIER* FIATAL NŐI ÉLETUTAK SZOCIÁLIS KONSTRUKCIÓS MEGKÖZELÍTÉSBEN
}

\author{
KENDE ANNA \\ Ph.D. hallgató
}

Pécsi Tudományegyetem, Pszichológiai Intézet, Elméleti pszichoanalízis szakirány E-mail: jabremer@freemail.hu

\begin{abstract}
A tanulmány mélyinterjús technikával készült empirikus kutatásról számol be, amely húsz fiatal értelmiségi nö életútján keresztül igyekszik elemezni a nemekkel és nöiséggel kapcsolatos társadalmi elvárásokat és személyes tapasztalatokat. A kutatás hátteréül szolgáló szociális konstrukciós elmélet lehetövé teszi, hogy a biológiai különbségek tárgyalásán túllépve, a nöiség fogalmát a testbe, társadalomba és személyes élményekbe ágyazottan értelmezzük. Az interjúk tartalomelemzése során kiderül, hogy a nöi szerepekkel kapcsolatos ellentmondásos elvárások közül a csoport tagjainak egy része az egalitáriánus, míg mások a konzervatív szemlélettel azonosulnak, illetve megismerjük, hogy a kiválasztott értékrend harmonikusan vagy konfliktusosan épül-e be az életútba. Az igy keletkezett négy csoport jellemzése annak megértéséhez igyekszik hozzájárulni, hogy jelen társadalmi változások milyen hatást gyakorolnak a személyes életutakra a nemi szerepek terén.
\end{abstract}

Kulcsszavak: nemi identitás, szociális konstrukció egalitáriánus/konzervatív értékrend, életútinterjú

\section{NEMI IDENTITÁS ÉS SZOCIÁLIS KONSTRUKCIÓ}

A nemek szociális konstrukciós elméletei olyan megközelítések, melyek a nem fogalmát a társadalom által kialakított kategóriáknak tekintik (WEITZ, 1998, TIEFER, 1995). Ennek megfelelően elvetik azt a nézetet, hogy a nemi kategóriák

* Ez a tanulmány az OKTK által finanszírozott, Neményi Máriával közösen végzett kutatás keretében készült ( $A$ nöi szerep szociális reprezentációja - két generáció női szerepre vonatkozó felfogása). A Neményi Máriával írt összehasonlító tanulmány, mely a Replika 1999/35. számában jelent meg, így némi átfedést mutat jelen tanulmány szövegével. 
biológiailag predesztináltak, illetve a nők és férfiak társadalomban elfoglalt egyenlőtlen helyzetének kiindulópontja a reprodukcióban betöltött szerepek közötti különbség lenne. A szociális konstrukció különféle elméleteinek tudományos érvényességét azonban téves lenne csupán arra az egyetlen gondolatra felfüzni, hogy az elmélet erőteljes kritikát fogalmaz meg a biológiai meghatározottságra épülő szociobiológiai és pszichológiai elméletekkel szemben. Bár a szociobiológia a genotípus és fenotípus kapcsolataként ragadja meg a nemi különbségeket és ennek tulajdonképpen kritikai ellenpárját jelentheti némely szociális konstrukciós nézet, amely a testet kifejezetten mint a társadalom diskurzusai által interpretált jelenséget értelmezi (LAQUEUR, 1990; SCHIEBINGER, 1991; BUTLER, 1993), a kapcsolat mégsem ilyen egyszerü, az elképzelések e téren nem egységesek. A szociális konstrukció elméleteit így szükségtelen a természet és kultúra vagy a biológiai determináció és társadalmi hatások kétpólusú ellentétébe helyezni. A társadalmi konstrukció mint a nemekre vonatkozó interdiszciplináris elméletek kiindulópontja azért hódít teret a különböző tudományterületeken, mert érthetővé teszi a (nemi) identitás posztmodern elméletekben megjelenő pluralitását, és lehetővé teszi a nemekre vonatkozó kultúrközi azonosságok és másságok magyarázatát.

A szociális konstrukció különféle megközelítései több szempontból eltérnek egymástól. Egyfelől maga a társadalmi konstrukció fogalma is jelölhet olyan folyamatot, amely jelentést ad a biológiai nemi különbségeknek. Joan Scott állítása szerint a nem az a tudás, amely a testi különbségeknek jelentést kölcsönöz, ez a jelentés azonban társadalmi, kulturális és időbeli változásokat mutat (SCOTT, 1988). Másfelől az elméletek eltérnek egymástól abból a szempontból, mennyire radikálisan tartanak ki amellett, hogy a nemek csakis szociálisan konstruáltak. Linda Nicholson az elsők között állította, hogy a nemi kategóriák semmilyen szempontból nem épülnek a testi adottságokra, ezzel szemben a testi adottságok interpretációját erősen meghatározza a társadalom által definiált „nem”-fogalom (NichOLSON, 1994). Nicholsonnál is szélsőségesebb képviselője ennek az elképzelésnek Judith Butler, aki a nemet csakis manifeszt oldalában ragadja meg, amely létrehozza az általunk ismert és alapvetőnek tekintett nemi kategóriákat (BUTLER, 1993). Az egyes irányzatok ezenfelül abban is különböznek, hogy a nemi kategóriák mely sajátosságait tartják jelentősnek. Az egyik meghatározó felfogás képviselői a nemi kategóriák időbeli és kulturális sajátosságait kutatják. E felfogás képviselői többek között Laqueur és Schiebinger. Ők a történelem olyan fordulópontjaira igyekeztek rámutatni, amelyekben megváltozott a nemek fogalmának definiálása. Laqueur anatómiakönyveket tanulmányozva arra a következtetésre jutott, hogy a két nemről való gondolkodás nem feltétlenül a természet törvényeire épül, hiszen a XVII-XVIII. század előtt valójában egyetlen nemet határozott meg a nyugati társadalom, a férfiakét, melynek csupán egy variánsa volt a női nem (LAQUEUR, 1990). Schiebinger a csontvázábrázolások tanulmányozásával támasztotta alá ugyanezt a jelenséget (SCHIEBINGER, 1991).

A pszichológia számára talán inkább hasznosíthatók azok a kutatások, melyek az egyes életutak során lejátszódó szociális konstrukciós folyamatokat vizsgálják, a hagyományos szocializációs elméletek mellett, illetve azokra építve a fejlődés azon eseményeit írják le, melyek hozzájárulnak a nemek személyes szintű, de társadal- 
milag meghatározott jelentéseinek elsajátításaihoz. A jelen tanulmány tárgyát képező kutatás mind kérdésfeltevésében, mind módszertanában ehhez az utóbbi években kialakult irányzathoz csatlakozik, amely párhuzamosan fejlődött ki a pszichoanalitikus és a szociálpszichológiai tradíciókból, és amelyben az identitás elnyeri többszörös jelentését, melynek alapján egyaránt reflektál egy szélesebb társadalmi közegre és az egyén sajátos pszichodinamikus miliőjére (LÁszLó, 1998). A vizsgálat tehát női életutak vizsgálatán keresztül azt igyekszik feltárni, hogy egyrészt mit jelent nőnek lenni egy fiatal felnőtt korosztály számára, viszonylag kedvező szocioökonómiai státusú csoport képviselőjeként, az elmúlt 2-3 évtized változó gazdasági-politikai kontextusának keretein belül. Másrészt hogyan rekonstruálhatók a narratív beszámolókon keresztül a női identitás többszörösen összetett személyes és szociális aspektusai.

Nem véletlen, hogy Magyarországon az utóbbi években, míg Nyugat-Európában és az Egyesült Âllamokban az utóbbi évtizedekben nőtt meg az érdeklődés a szociológusok, antropológusok és pszichológusok körében a nemek témája iránt. A válasz egyrészt abban keresendő, hogy fokozatosan tudatosodott a kutatókban a férfiak és nők közötti kapcsolat jelentősége a társadalom felépítésében, de másrészt a nemi szerepelvárásokban bekövetkezett radikális változások is rákényszerítették a szakembereket, hogy elgondolkozzanak a nemi kategóriák jelentésén, annak gyökerein és változtathatóságán. A változások Magyarországon, bár a „Nyugattól” nem függetlenül, mégis másképp zajlottak. Itt a nemek társadalomban elfoglalt helyzetére leginkább a szocializmus négy és fél évtizede nyomta rá a bélyegét, illetve a rendszerváltás utáni közel egy évtized speciális gazdasági-társadalmi átalakulása hatott, amelybe azonban már bele-beleszövődik a nyugati típusú feminista irányzat hatása is.

\section{ELLENTMONDÁSOK A NŐI EGYENJOGÚSÁG SZOCIALISTA ÉS POSZTSZOCIALISTA FELFOGÁSAIBAN}

A szocialista rendszer a nemek szempontjából paradox helyzetet teremtett Magyarországon, hiszen rövid idő alatt, látványosan vívta ki a nyugati marxista feminista mozgalmak által elérhetetlennek tűnő célokat. Magyarországon és a többi volt szocialista országban a második világháború után a törvénykezés szovjet mintára hajtotta végre a női emancipációt: a gazdasági, kulturális, szociális és politikai élet minden terén meghirdette a nők egyenjogúságát. Törvényeket és szociális intézményeket hoztak létre a család és munkavállalás közötti konfliktusok megoldására. Az egyenjogúságot kvótákkal és pozitív diszkriminációs intézkedésekkel próbálták megvalósítani mind a nők, mind a társadalmi hierarchia alacsonyabb szintjein elhelyezkedő rétegek számára. A nők profitálhattak az ingyenes oktatásból, ingyenes egészségügyből, az államilag támogatott bölcsődékből és óvodákból, illetve a teljes körủ munkavállalás gazdasági előnyeiből (FERGE, 1985). A helyzet meghatározó körülménye ugyanakkor, hogy a nők törvényi védelmének alapját elsősorban nem szociális, hanem „természetes” státusuk képezte. A termelés (produkció) és 
szaporodás (reprodukció) felelősségének nemek közötti elosztása ugyanis szintén a kötelezettségek természetes elosztásához tartozott (CORRIN, 1992; TóTH, 1993).

A teljes körủ női munkavállalás ellenére a nők keresete a férfiak jövedelmének átlagosan csak 70\%-át tette ki, így - bár a családok rá voltak szorulva a két fizetésre - a nők munkavállalásának normává emelése miatt a házimunka és gyereknevelés alacsonyabb rendủnek minősült, mint a jövedelemszerző tevékenység. Mindezekből következik, hogy a nők elsősorban gazdasági okokból, de egyúttal és egyre inkább az önmegvalósítás igényével is vállaltak munkát. Mindemellett, illetve mindennek ellenére a család ezekben az évtizedekben még hangsúlyosabban vált az identitás alakulásának színterévé, hiszen a szocializmus időszakában a család jelentette az egyetlen olyan menedéket, ahova az ideológiai kontroll nem tudott beférkőzni. Férfi és nő, férj és feleség a hatalom és a társadalom szembenállásában nem riválisok, hanem szövetségesek voltak, így érthető, hogy a nők nem a férfiakon kérték számon egyenlőtlen helyzetük javítását (NEMÉNYI, 1994; MARODY, 1993).

A helyzet ellentmondásossága így többek között abból adódott, hogy a női emancipáció nem alulról építkező folyamat volt, ezért az eredményeket mind a nő-, mind a férfitársadalom ambivalensen fogadta; az egyenlőséget sem a nyilvános szférában, sem a magánszférában nem sikerült megvalósítani; minthogy a törvényi keret mögött ideológiai célok húzódtak meg, az egyes intézkedések egymásnak ellentmondó hatásokat váltottak ki, amelynek eredménye például a munkaerőpiac újfajta nemi szegregálódása (EINHORN, 1993). Mindehhez hozzájárult, hogy a totalitáriánus rendszer infantilizálta a társadalmat, a nemek egyenjogúságát tényként kezelte, ezzel teljesen elfojtva a nők tudatosodásának lehetőségét.

A hatvanas években a munkaerőpiac telítettsége és ezzel együtt a népesség stagnálása, illetve fenyegető csökkenése rákényszerítette az államot különböző, tradicionálisnak is tekinthető családcentrikus intézkedések - mint például 1967ben a GYES és 1981-ben a GYED - bevezetésére (SÁNDORNÉ, 1986). A női emancipáció ambivalenciákkal terhelt fogadtatása, illetve a női szerepekben rejlő ellentmondások fel nem ismerése erőteljesen hozzájárult ahhoz, hogy a hatvanas években egyre inkább terjedő konzervatív ideológia táptalajra találjon a társadalomban. A nők jelentős hányada igénybe vette azokat az intézményeket, amelyek lehetővé tették számukra a családi és munkahelyi kötelezettségek közötti feszültség feloldását és a hagyományos női vagy anyaszerepük visszavételét. Amit a korai egyenjogúsítási intézkedések mindaddig a szőnyeg alá söpörtek, a hatvanas években a felszínre bukkanhatott. Bár a társadalom nagy részének jobban megfelelt az új, konzervatívabb norma, mint a korábbi, ez a női emancipáció radikális előretörésének szakaszához hasonlóan ellentmondásos volt. Még az 1990-es rendszerváltás után is csak kevesen ismerték fel, hogy a probléma forrása az elv, a törvényi keret és a mindennapos valóság ellentmondásában keresendő (KONCZ, 1994; NEMÉNYi, TóTH, 1998). A konzervatív értékek újraéledése lehetetlenné tette, hogy az ellentmondásosság nyilvánosságot kapjon, így a mindenki számára problémaként kezelt jelenségeket - például válások nagy száma, alacsony születési szám - alapvetően tradicionális irányba mutató megoldásokkal igyekeztek orvosolni.

A rendszerváltás utáni időszakban a hagyományos család iránti nosztalgia még 
inkább felerősödött, és a családi élet boldogsága megelőzte a karrier, a társadalmi pozíció, a politikai vagy társadalmi aktivitás fontosságát ${ }^{1}$. Emellett a tradicionális életforma sokak számára a választás lehetőségét jelentette, ez szintén elősegítette a család értékének megnövekedését. A családdal kapcsolatos attitűdök jól szemléltetik, hogy ma Magyarországon alapvetően kétirányú hatás érvényesül. Egyrészt a civil társadalom megerősödése és a nyugati befolyás miatt a nők alulról kezdeményezett emancipációs törekvései felgyorsultak, a nők teret követelnek maguknak a hagyományosan férfiaknak fenntartott nyilvános szférában. Emellett elmondható az is, hogy a férfiakhoz hasonlóan élni szeretnének a kiszélesedett karrier- és magas jövedelemszerzési lehetőségekkel (NAGY, 1997). Mások számára viszont éppen arra nyílt lehetőség, hogy visszaköveteljék maguknak mindazt, amit éppen a korábban leírt ellentmondásosság miatt a szocializmus éveiben - érzésük szerint elvettek tőlük: a tradicionális női szerepeket. A társadalom jelentős részének választási lehetőségét azonban korlátozza a rossz gazdasági helyzet, férfiakat és nőket egyaránt fenyeget a munkanélküliség, illetve a szociális juttatások csökkenése miatt gyakran még két kereső szülő jövedelme sem elegendő a család fenntartásához. A jóléti társadalom megingásával a legnehezebb helyzetbe az egykeresős, illetve az egyetlen szülő által vezetett háztartások kerültek, ilyen a családok egyhetede, melynek 80\%-a nő által eltartott család (ADAMIK, 1993). Ezek a változások is igazolják azt a közgazdászok, szociológusok és politológusok által sokat hangoztatott állítást, hogy ma a társadalom szegény és gazdag rétegekre történő kettészakadásának vagyunk tanúi. A szakadék azonban nemcsak az egyes szociális csoportok között tátong, hanem - a korábban említett új karrierlehetőségek eredményeképpen - az is megfigyelhető, hogy a társadalmi munkamegosztásba újonnan belépő fiatal generációk lehetőségei sokszorosan meghaladják az előttük járókéit, azonban egyúttal a lecsúszás veszélye is sokszorosan érinti ezt a korosztályt. Mindez hatalmas kihívást jelent a fiatal női generációk számára.

\section{NŐI ÉLETUTAK VIZSGÁLATA}

A mélyinterjúkra alapozott kutatást egy speciális csoport körében folytattam: saját gimnáziumi osztálytársaim képezték a mintát. A választás azért esett éppen erre a csoportra, mivel ők azt a fiatal korosztályt reprezentálják, amely a pályaválasztás, családalapítás küszöbén áll, amikor a női szerepekkel kapcsolatos választások még nyitottak, viszont elmondható, hogy már nem absztrakt szinten jelennek meg,

${ }^{1}$ Egy nemzetközi vizsgálat, melynek keretében több európai országban feltették a kérdést: „Kinek jobb az életben?”, kiemelkedő családcentrikusságot mutatott Magyarország esetében. A magyar mintában a válaszoló anyák $89,2 \%$-a szerint a gyermekesebbeknek jobb az élete. Ezzel szemben a nyugati válaszolók, de még a többi volt szocialista ország megkérdezettjei is majdnem tökéletesen ellentétes válaszokat adtak a feltett kérdésre (PONGRÁCZNÉ, 1994). A szociológiai kutatás mellett ezt igazolja számos újonnan megjelenő, nőknek szóló és igen konzervatív értékrendet sugalló sajtótermék is - pl. Kiskegyed, Ỏnagysága stb. -, amelyek hatását olyan nyugati mintára készült magazinok is csak nehézkesen tudják ellensúlyozni, mint a Cosmopolitan, ahol az emancipált nőmodellnek egy sajátos és szélsőséges sztereotípiájával találkozunk. 
hanem a hétköznapokhoz kötötten. Ez a generáció éppen a rendszerváltás éveiben került az életet hosszú távon meghatározó választások és döntések elé, amelyeket a társadalom politikai-gazdasági szerkezetében és domináns ideológiai hatásában bekövetkezett változások nagymértékben érinthetnek. A módszer igazolásához tartozó további elem, hogy e vizsgálatban olyan ismerősöket szólaltattam meg, akikkel nincsen napi szintű kapcsolatom - ez torzíthatná az eredményeket -, de a mégis létező, régi ismeretség megkönnyíti a beszélgetés fonalának felvételét, az intimitás megfelelő szintjének kialakítását. Tehát azt lehetett remélni, hogy ez az igen laza szállal összekötött, mégis valamilyen láthatatlan hálóban elhelyezkedő csoport ideális célcsoportot jelent a kutatás számára, mivel a jelen társadalmi kontextusában létező és a módszertan sajátosságainak maximálisan megfelelő viszony állt fenn kérdező és kérdezett között.

A leíró-feltáró jellegü kutatás, amit végeztem, az egyes emberek személyes élményeinek részletes megismerésén alapszik. Az interjúkban arra voltam kíváncsi, hogy az egyéni életutakban hogyan jelenik meg a nem, a nőiség, és ez milyen további elvárásokhoz, elképzelésekhez vezet. Igyekeztem feltárni, hogyan viszonyul az egyén a nőkkel kapcsolatos társadalmi diskurzusokhoz, azok hogyan hatnak rá, milyen rendelkezésre álló női szerepekből választ(hat) magának a megkérdezett személy, és azoknak hogyan ad egyéni színezetet. Az interjúk néhány sajátos témakör köré csoportosultak, ami lehetővé tette a csoport együttes elemzését, az egyes életutak összehasonlítását, s ráirányította a figyelmet a többször előforduló, általánosabb jelenségekre.

A kérdések egy része a gyermekkorra, a szülőkre és a családi háttérre vonatkozott. Itt elsősorban arra voltam kíváncsi, hogy válaszolóim milyen családi környezetben nőttek fel, milyen példát jelentett számukra a szülők egymáshoz való viszonya, munkamegosztása, milyen modellek voltak jelen interjúalanyaim életében. A múlt feltárásához tartoznak az iskola- és pályaválasztással kapcsolatos döntések, a múltban szőtt tervek, de kérdéseim a magánéletre, baráti és szerelmi kapcsolatokra és a szexualitásra is kiterjedtek. Mindezek leginkább a jelenre és jövőre gyakorolt hatásuk szempontjából voltak érdekesek számomra. Azt reméltem a válaszokból megtudni, hogy milyen hatással voltak a leírt élmények a megkérdezettek nőiségének alakulására, a jövővel kapcsolatos elvárásokra. Amellett, hogy beszéltünk interjúalanyaim konkrét terveiről, szakmai esélyeikre és magánéletükre vonatkozó távolabbi elképzeléseik is érdekeltek. Végül a nők társadalmi helyzetét globális perspektívából közelítettük meg, megkérdeztem, ők hogyan látják a (fiatal) nők helyzetét ma Magyarországon. Itt azt vártam, hogy a nők és férfiak társadalmi szerepének általános megítélésére vonatkozó vélemények kapcsán felszínre törnek a sztereotipikus nézetek, a torzítottan átvett képek, azok az uralkodó vagy éppen marginális elképzelések, amelyek erősen befolyásolják mind a saját életük alakulását, mind a társadalomban fennálló nőképet - a nőiség szociális konstrukcióját.

1997/98-ban, a vizsgálat lefolytatásának idején a húsz megkérdezett személy 24-25 éves volt. Négyen közülük már férjhez mentek és gyerekük is van, illetve egy válaszoló volt terhes az interjú készítésekor. Az interjúkészítés idején az anyák mindegyike GYES-en volt. Ketten egygyermekesek, a másik két anyának kettő, illetve három gyermeke van. Az osztály tagjai a gimnázium után egy kivétellel 
mind továbbtanultak. Eddig tizen szereztek egyetemi vagy főiskolai diplomát, ketten végeztek el valamilyen képesítést adó tanfolyamot és nyolcan járnak jelenleg is felsőoktatási intézménybe. Talán érdemes megemlíteni, hogy négyen jártak, illetve járnak jogi egyetemre, öten végeztek vagy végeznek tanári, tanítói képesítést nyújtó intézményben. Van, aki a műszaki egyetemen szerzett diplomát, egy másik az államigazgatási föiskolán, hárman a bölcsészkarra járnak, egy fö készül gyógyszerésznek. Nyolcan dolgoznak főállásban, mindannyian szakmájuk területén.

Tizenöt válaszoló szülei felsőfokú végzettségủek, további négy esetben az egyik szülő végzettsége technikumi, míg a másiké egyetemi vagy főiskolai diploma. Ezekben az esetekben rendre az anyának volt alacsonyabb végzettsége, csak egy olyan családot találunk, ahol az apa technikumot végzett, s az anya középfokú végzettséggel rendelkezik. Tizenöt esetben élnek együtt ma is a szülők, három válaszolónak halt meg egyik szülője még 18 éves kora elött (egy esetben az anya és két esetben az apa), és két helyen fordult elő válás még a gyerekkor idején. A családok többségében (13 válaszolónál) két gyermek nevelkedett, három esetben nincsen, négy esetben pedig két testvére van a megkérdezettnek. Mivel minden esetben dolgozó anyákról van szó, érdekes adatszerủen bemutatni azt is, hogy az anya mennyi időt töltött otthon a szülést követően. Öt válaszolóm anyja több mint hét évet töltött otthon. Egy kivétellel a több gyerek születése miatt maradhattak az anyák ilyen hosszú ideig GYES-en, de volt olyan anya, aki otthoni bedolgozást vállalt, hogy a GYES után is együtt maradhasson a gyerekeivel. Szintén öt anya töltött el otthon kettő és négy év közötti időt, és nyolc anya volt otthon kevesebb, mint másfél évig. Két interjúalanyom nem tudott pontos választ adni, de mindkét esetben arról van szó, hogy az anya sokat volt otthon, elsősorban kötetlen munkája miatt. Tizen említették azt, hogy a nagymama vagy nagynéni aktívan részt vett a nevelésben és a háztartásban is, ezzel a legtöbb esetben felváltva az anyát. Ezekben az esetekben az anya összes gyerekével mindig kevesebb, mint három évet volt otthon. A megkérdezetteknek éppen a fele járt bölcsödébe, a többi vagy az anyával, vagy az említett rokonokkal töltötte az első három évet. Óvodába mindenki járt három éves korától kezdve. Összességében elmondható, hogy a korról általánosan elmondottak nyomon követhetők mind a szülők, mind a megkérdezettek adatainak feltárásakor, de észrevehető az is, hogy értelmiségi családokról beszélünk, akik a szocializmus és poszt-szocializmus éveit is sajátosan élték meg. Az anyák mindegyike dolgozott, magas iskolai végzettséggel rendelkezett, de többségük jócskán kihasználta a hetvenes évek liberalizálódását és a nők családi szerepkörét támogató intézkedéseit.

\section{SZÖVEGELEMZÉSEK}

A mélyinterjúk feldolgozása kvalitatív tartalomelemzés útján történt, tehát az egyes témákkal kapcsolatos egyéni tapasztalatokat hasonlítottam össze. A tanulmány szövegébe bevont idézetekkel csupán szemléltetni kívánom a bemutatásra kerülő véleményeket és jelenségeket, hiszen az eredmények természetesen az in- 
terjúk teljes egészéből álltak elő. Az elemzés alapfeltevése szerint a megkérdezett személyek ahhoz a generációhoz tartoznak, ahol a konzervatív és egalitáriánus vagy emancipált értékrend közötti választás realitása rányomja a bélyegét mind a múlt értékelésére, mind az előrevetített életcélokra. A feltétezés alapjául a bevezetőben ismertetett történeti-társadalmi kontextus szolgál, mely szerint a megkérdezett életében a női munkavállalás már természetes és széles körben elfogadott volt, azonban ezzel egy időben a nők hagyományos feladatai - mint a gyereknevelés és háztartás - továbbra is megőrződtek mind intézményesen (GYES, GYED, családi pótlék), mind a gyakorlati értelemben a kétkeresős családmodellen belül is. A szülői korosztály is abban a társadalmi rendszerben nevelkedett, melyben a női emancipáció hivatalos ideológia volt, ám az emancipáció eredményeinek internalizációja a szülők/anyák részéről ambivalensen történt.

A kiválasztott generáció esetében fontos tényezőnek tekinthető a 1989/90-ben elkezdődött rendszerváltás folyamata. Az államszocializmust felváltó plurális demokrácia keretei között a nők számára elérhetőbbé vált a szerepek közötti választás. Az átalakulást követő gazdasági nehézségek ellenére is megnőtt a személyeknek sajátosan megfelelő életforma melletti döntés szabadsága, többek között olyan jelenségek megjelenésével, mint a munkanélküliség legitim státusa vagy az egyéni vállalkozások lehetővé tétele. Mivel a megkérdezettek éppen a rendszerváltást követő évben érettségiztek, így számukra az emancipált vagy a tradicionális szerepmodell közötti választás már úgymond önként történhetett.

A feltételezéssel összhangban a megkérdezettek többsége két, egymástól jól elkülönülő csoportba volt sorolható. A két csoport jól képviseli a válaszadók elveit és értékeit a már megélt és az anticipált életutjukra vonatkozóan. Az egymásnak gyakorlatilag ellentmondó értékrendek az életútinterjúk központi elemének tekinthetők, hiszen minden kérdés e dimenzió mentén került megtárgyalásra. ${ }^{2}$ A kategóriákat a konzervatív és emancipált jelzőkkel lehet jellemezni, ebben a kettősségben helyezhetők el a megkeresett személyek alapvető értékei. A két csoportba sorolt személyek életutjai mellett megismerkedtem kevésbé egyértelműen kategorizálható életutakkal. Bár a megjelölt értékkategória egyértelmủen azonosítható volt, a választott életstílust sokszor bizonytalanul, önellentmondásokba keveredve jelenítették meg. Számukra attól függetlenül, hogy a választás az emancipált vagy a konzervatív ideál mellett történt, nem tűnt problémamentes, belső konfliktusok nélkül megvalósíthatónak. A megkérdezetteket tehát valójában két dimenzió mentén kell csoportosítani: az egyik dimenziót az emancipált és konzervatív életideál választása alkotja, a másik dimenziót pedig az adott életút harmonikus vagy konfliktusos megvalósítása jelenti.

\footnotetext{
2 Egyetlen téma volt gyakorlatilag irreleváns az értékrend szempontjából: a szexualitás. Hacsak nem a valláserkölcs szabályozta a szexuális viselkedést, ezt a témát senki nem kapcsolta össze az élet egyéb, akár a párkapcsolatra is vonatkoztatott elvárásaival, így az emancipatorikus és a konzervatív értékrenddel sem. Bár nem egyformán alakultak a szexuális tapasztalatok a megkérdezettek mindegyikénél, a különbségek az érettségből, a kortárs befolyástól, a szülői hatásoktól függtek, és sokszor a véletlenszerủen adott körülmények szerint alakultak. Ugyan elmondható, hogy azok a személyek, akik vallásos életvitelűek, mind konzervatív értékrendet is vallanak, ez azonban nem közvetlenül, hanem a vallási előírásokon keresztül hatott ki a szexualitásra.
} 


\section{A (HARMONIKUS) KONZERVATÍV CSOPORT}

Öt megkérdezett alkotta ezt a csoportot, tehát az ő véleményeiket tükrözi, illetve az ő interjúiknak rövid összefoglalójaként értelmezhető a következő leírás. Az öt személy között szerepel a négy anya, akik elégedettek jelenlegi szerepkörükkel, és a jövőt a jelenhez hasonlóan képzelik el, illetve egyébirányú céljaikat alávetik a jelenleg domináns szerepüknek: az anyaszerepnek. Az ötödik válaszoló, akit ide soroltam a négy anyához nagyon hasonló jövőt képzel el magának, illetve modelljének is tekinti az egyik volt osztálytársát, aki ma már több gyermek anyja.

Konzervatív felfogásúnak tekintem azt, akinek értékrendjében, nemi szerepekről alkotott felfogásában központi helyen áll a nő és a családi szerep összekapcsolása, aki egyúttal a férfinek való alárendeltséget nemcsak elfogadja, hanem annak megváltozását negatívan értékeli, ezenkívül aki külső okokból és nem belső motivációk alapján vállal munkát, és úgy érzi, hogy a nők munkavállalása a gyermek nevelkedésére károsan hat, azt gondolja, hogy az anyának a gyerekkel az első néhány évet otthon kell töltenie, és mindezek mellett a női emancipáció legtöbb aspektusát elítéli.

A harmonikus-konzervatív csoport tagjaira jellemző volt, hogy soha nem vélekedtek pozitívan az anyák karriersikeréről, azt mindig úgy tekintették, hogy a gyereknevelés kárára történt.

- Minél többet együtt lenni a gyerekkel, minél többet megadni nekik olyat, amit én nem kaptam meg, kirándulás, szeretet, mindenböl egy kicsit hiányosnak érzem, amit kaptam. (05)

- Mi bölcsődések voltunk, óvodások voltunk, ezt már nem lehet visszacsinálni, az anyukám akkor még nem bánta, akkor a munka álfrontján volt. Nagyon hajtotta magát. Arra emlékszem, hogy egyszer ki lehetett menni Bécsbe, akkor én kb. hároméves lehettem, és nagyon sirtam, hogy ne menjen ki, mert féltem, hogy nem jön vissza. Elment egy hétre, ez nekünk hosszú idö volt, ez nagyon rossz volt. (19)

Ebben a csoportban tapasztalhattuk leginkább, hogy a női modellek a családi mintát vagy a nőiesség példáját nyújtották.

- Van egy unokatestvérem, akinek négy gyereke van és Svájcban él az ugyancsak magyar férjével, és én voltam kint náluk 16 éves koromban, egy hétig laktam ott, és ez nagyon mély nyomokat hagyott bennem, szóval nekem, ha család, akkor ők a modell, úgy, ahogy vannak. És azalatt az egy hét alatt nagyon sokat tanultam tôlük. (02)

- A P. is nagy hatással van rám, hogy már három..., most talán megint terhes a negyedikkel, most hogy márciusban szült, úgyhogy azért ekkora nagyon nagy családot nem szeretnék, de látszik rajtuk, hogy nagyon boldogok, tehát tényleg látod óket, és azt gondolod, hogy ez igen. Nem azt mondom, hogy felveti óket a pénz, de egyszerüen szeretetben élnek, és azért ez olyan jó példa, csomó embert látni, hogy megszületik a gyerek és csak azt mondják, hogy jaj mennyibe kerül a pelenka, és tényleg annyiba kerül és a P.ék is ugyanannyiért veszik, csak éppen nem azt az oldalát fogják meg a dolgoknak. Inkább erre vagyok nyitott, szeretnék nyitott lenni. (05) 
A párkapcsolatokban a megkérdezettek nem tartottak igényt egalitáriánus viszonyra, elfogadták, hogy a férfi szerepei a családon kívüliek, míg a nőnek otthon kell érvényesülnie, így az is elfogadható, ha a férfi tartja el a nőt.

- Szerintem a családfó az férfi, és ô dirigál, mármint jó értelemben, ez szerintem a férfiaknak is kell. (...) én próbálom úgy várni a férjem, nekem van egy elképzelésem arról, hogy hogy kell várni, ha egész nap dolgozik, meg ott van az emberek között, és lehet, hogy jobb lenne neki, hogyha nyugalom lenne, vagy csend lenne, és próbálok ráhangolódni erre. (19)

- Az az igazság, hogy tök jó lenne, hogyha a G. el tudna minket tartani, szóval én leginkább késóbb is úgy képzelem el, hogy a gyerekeknek nem kell a napköziben 5-ig csücsülni, hanem megtanultak, és kettöre értük mehetek, és elviszem az úszásra, és megnézem, hogy mit csinálnak, és elmegyünk ide-oda, amoda. (03)

A konzervatív csoportba sorolt megkérdezettek egyöntetű véleménye alapján kirajzolódik, hogy ugyan igénylik, hogy a férfi nyújtson némi segítséget otthon, és foglalkozzon a gyerekkel, de csak azon a szinten, hogy a családban érződjön az apa jelenléte, illetve, hogy bizonyos terheket levegyen a feleségről, de nincs szó a kötelességek és szerepek kiegyenlítéséről. A munkáról alkotott elképzeléseket elsősorban a külső kényszer alakítja, ami gyakorlatilag akkor lép fel, amikor az anyák már nem jogosultak az állam által biztosított családi támogatásokra. Ennek ellenére volt rá két példa, hogy bizonyos konkrét munkára elhivatottnak érzi magát a személy, amit akkor végezne csak, mikor nagyobbak már a gyerekei, és otthon saját megítélése szerint sincs szükség az anya állandó jelenlétére, illetve ha gazdasági kényszerből rászorulna a munkavégzésre.

- A kollégámmal gondolkoztunk azon, akivel jóban vagyok nagyon, hogy meg kéne teremteni az utazási irodának a konkurenciáját, mert tudjuk, hogy mit nem kéne igy csinálni, meg mi nagyon jó így, ö is szeretne egy-két éven belül szülni, és azt terveznénk, hogy ezután, miután mind a ketten szülttünk, meg nem egy hónap vagy egy év után szeretnénk visszamenni dolgozni, hanem utána meg kéne csinálni egy ilyet. (05)

A konzervatív csoportba sorolható személyek között egyöntetủ vélemény volt az is, hogy több (kettő-háromnál több) gyereket is szeretnének, és otthon szeretnének maradni a gyerekeikkel, ameddig csak lehet.

- Öt, hat, hét, körülbelül, tehát ezzel most csak azt akarom mondani, hogy háromnégynél többet szeretnék, de nem szeretnék nyolc-tizet, de ha nyolc-tíz gyerekem lesz, akkor örülni fogok nekik, és azért fogok imádkozni, hogy fel tudjam óket nevelni. (08)

- Mivel ö császáros baba lett a végén, mi szerettünk volna, vagyis hát most is szeretnénk testvért neki, mert egyedül nem maradhat, de az, hogy nagycsalád legyen, az egy kicsit megingott, mert négy-öt gyereket szerettünk volna. (19) 
Óvodába (egy esetben bölcsödébe is) elsősorban azért adnák a gyerekeiket, hogy szokja a közösséget, és nem azért, hogy saját karrierterveiket megvalósíthassák. Ezek a válaszolók a munka és a család dilemmáját külső kényszerek alapján fogalmazzák meg, de ez nem okoz belső konfliktust, ugyanis döntésükben egyértelműen a család áll első helyen, amely nem szenvedhet kárt a nő családon kívüli ambíciói miatt.

- A legfontosabb most az, hogy feleség és anya vagyok, és szerintem mindig is ez lesz a legfontosabb. (02)

Ezzel összefüggésben a szocialista nőképet is azért ítélik el, mert az felborította a tradicionális családmodellt.

- Hát szerintem itt borult meg az az egyensúly, ami régen megvolt, hogy az asszony otthon volt, a családjának élt, otthon látta el a teendóket, és kevesebb pénzböl is, de megéltek, ez felborult, mert én azt gondolom... bár végül is ha tanult, szóval itt van a baj, ha már tanult és dolgozott, akkor miért ne legyen olyan beosztása, szerintem a mai világ az nagyon elviszi ebben az irányban a dolgokat, mindent, én ezeken úgy annyira nem nagyon szoktam gondolkodni, én nem emancipálódom, az biztos. (19)

- A család az biztos megsínylette, amit én magamon is láttam, hogy az én anyukám soha nem volt otthon, amikor hazamentem az iskolából, hogy soha nem volt otthon velem nyáron, a család az biztosan, hogy a nök idegesek lettek, mindenféle terhet kell viselni, az mindenképpen... (05)

A rendszerváltással kapcsolatban elsősorban a korábban nem tapasztalt anyagi nehézségekről, a szociális háló megszűnéséről beszélnek. A rendszerváltás után „kitermelődött” sikeres nőkről igen negatív képet festenek. Jellemző volt, hogy szinte mindenki úgy kezelte a saját konzervativizmusát, hogy ez ma a társadalomban egy marginális csoport értékrendje.

- A társadalom leértékeli az anyaszerepet, tehát sokkal nagyobbra tartják, hogy elmegy valaki karriert készíteni, mint azt, hogy otthon marad a gyerekével. (08)

- Kicsit más az értékrendem, mint a nagyátlagnak. Fontosabb a család, fontosabbak, mint a külsőségek, én nem vagyok olyan, aki hajhássza az életet, és minél több programot belesürit az életbe, meg ilyen nagyon intenzíven él. (02)

A nemi szerepek közötti különbségtétel a konzervatív csoportba sorolt személyeknél kizárólag egy igen esszencialista felfogást tükrözött, miszerint a nemi (szerep)különbségek eredetéért csakis biológiai okok és nem társadalmi tényezők felelősek.

- Egy nönek a lelkülete más, finomabb lelkek, és egy csomó dologhoz pont erre van szükség, például az emberekkel való kapcsolatban. Vagy például a nök precízebbek, mint a 
férfiak, tehát van egy csomó munka, ahol ezt igénylik, de állítólag a férfiak térlátása jobb, mint a nóké. (13)

- A nö az alapvetöen lelki típus, hát így kiegészítik egymást. Alapvetö gének miatt, kész, a férfi az racionálisan látja a dolgokat, a nöben meg benne van egy kis álmodozás, és akkor találkoznak, én ezt nem tudom jobban kifejteni, de biztos, hogy vannak különbségek, és ez így jó. (19)

\section{A (HARMONIKUS) EMANCIPÁLT VAGY EGALITÁRIÁNUS CSOPORT}

Nyolc interjúalany válaszaiból állítottam össze ezt a csoportot. Közülük mindenki egyetemet végzett vagy egyetemre jár még mindig; hatan állandó partnerrel rendelkeznek, s egyikük az interjú idején várta első gyermekét. A csoportot a mintán belül tulajdonképpen azok alkotják, akik többé-kevésbé megállapodottak a partnerkapcsolat terén, de még nincsen családjuk, és szakmájukat illetően aránylag egyértelmü elképzeléseik vannak.

Emancipáltnak nevezem azt a személyt, akinek belső motívumoktól vezérelt karriertervei vannak, aki a családot úgy képzeli el, mint férfi és nő közös életterét, elvárása, hogy a férfi egyenlő partnernek tekintse őt, ezért támogassa karrierterveit, vegyen részt a család életében, a háztartásban és a gyereknevelésben, aki úgy érzi, hogy a családnak, gyerekszülésnek és a munkának egyaránt alkalmazkodnia kell egymáshoz, és a kettő csak kompromisszumok árán oldható meg.

Az emancipált csoport gyakorlatilag minden, az értékrend szempontjából releváns témánál eltérő álláspontot fogalmazott meg, mint az előbb ismertetett tradicionális csoport. A megkérdezettek ebben a csoportban szüleikkel kapcsolatban pozitívan értékelték, ha az anyának sikerült a munka terén elért eredmények mellett a családot is ellátnia.

- A munkáról azt mondom, hogy imádta a munkáját, amit most már nem csinálhat, nagyon szerette, nagyon nagy örömet okozott neki, felüdülés volt neki egyrészt a gyerekei a munkából, másrészt a munka gyerekeiböl. Szóval nagyon jól tudta ezt összehangolni, és ez máig is így van. (06)

- Az anyukám kifejezetten energikus, rettentöen univerzális bírt lenni, a mai napig, ha kell felkel hatkor, megfözi az ebédet, idehurcolja, majd bemegy, és szombaton is dolgozik, és ezt ő tudta huzamosabb ideig, mindig legalább két mellékállással dolgozott a föállása mellett, és háztartást vezetett, de ragyogóan, kitakaritott, fözött, és egy olyan teljesen komplett háztartást vezetett, hogy a papám mennyire vette ki ebböl a részét, azt nem tudom, volt olyan, hogy kitakaritott, meg elmosogatott. (20)

Pozitívan értékelték, ha az apa kilépett a tradicionális szerepből, és elégedetlenek voltak azzal, ha nagyon tartotta magát a tradicionális férfi szerepekhez. 
- Szóval a papa olyan volt, mintha vendégként élt volna velünk. (06)

- Az tetszik, hogy apu ennyit megcsinál, mert máshol ennyit sem csinál meg egy férj, meg az tetszik, hogy apu föz a hétvégén. (13)

- A mamám fiatal orvos volt, fiatalon szült, és akkor sokszor kellett ügyelnie, csomószor nem volt otthon hétvégeken, akkor a papám látta el az anyai feladatokat. (11)

Az ő modelljeik intellektuális tulajdonságaik miatt váltak modellé, vagy a munkacsalád dilemmának a megoldásában nyújtanak - néha sajátságos - mintát.

- Nagynéném késön ment férjhez, és akkor már nem akart gyereket, ő abban számít modellnek, hogy eleve nagyon okos, meg nagyon igazságos, preciz. Abban nem modell a nagynéném, hogy mindent a férje feneke alá tesz, tényleg a férje csak ül a fotelben, és ő kiszolgálja (...) A barátnőm az, aki ilyen családdal kapcsolatos modell, ö teljesen föladta a karrierjét, én nem tudom, hogy mit fogok csinálni, de ahogy ö csinálja, az nagyon tetszik. Mindene a gyerekei, nagyon tudatos, de az ö természete nagyon más, mint az enyém. Meg az, hogy a férjének van egy gyereke, az a gyerek nem birja M.-et, ezért a férj egy külön lakásban él a lányával, végül is ö úgy neveli a gyerekeit, mintha egyedül lenne, annak ellenére, hogy van férje. (13)

Az interjúkból egyértelműen rajzolódott ki az a vélemény, hogy szakmai karrierje alapvetően meghatározza egy nő boldogulását. Vágyaik, elképzeléseik azt sugallják, hogy munkájuk az önmegvalósítás és az életszínvonal megteremtésének legfőbb eszköze.

- Nem vagyok benne biztos, hogy még harminc év múlva is ezt fogom csinálni, most ezt nagyon élvezem, és én még mindig filózok ezen a Ph.D.-n, én már az egyetemen is demonstrátorkodtam, tanítottam, tehát végeznék mindenféle kutatómunkát is, csak úgy gondoltam, hogy fontos azért ez a két lábon állás is, tehát, hogy valami másik területen is szerezzek diplomát. (16)

- Egy tök jó irodában vagyok, erre van esélyem, hogyha én itt dolgozom, az én fönököm 30 éves és a karrierje csúcsán van, vagy legalábbis közel, tehát ilyen szempontból jók az esélyeim. (11)

- Szüleimnek van egy ilyen kis kétszemélyes cége, tolmács, fordító, és hát ott fogok dolgozni valószínüleg, de amit a legjobban szeretnék, az EU-ban dolgozni, tolmácsként, de ahhoz rengeteget kell tanulni, ahhoz még korántsem tudok semmit. (15)

A párkapcsolatokban az emancipáltnak tekintett személyek egalitáriánus kapcsolatra törekednek, ami egyrészt pszichológiai szinten elvárás, tehát az az igény fogalmazódik meg benne, hogy a felek tekintsék egymást egyenlőnek, másrészt konkrét feladatokban, családi kötelességekben megvalósuló egyenlőséget jelent. Az otthoni munkamegosztásra gyakorlati okok miatt is igényt tartanak, hiszen 
konkrét szakmai ambícióik vannak, amelyeket motiválhat a pénzkeresés, de mindig megjelennek mellette a belső motívumok is.

- Úgy érezem, hogy az elózó barátomtól sokkal jobban függtem. Ilyen szintre nem akarok kerülni. Nála (jelenlegi barátnál) is van olyan, hogy nem hív föl, akkor ideges vagyok, de kialakult egy olyan kontrollom, hogy nem engedem, hogy befolyásoljon. Nem lakunk együtt, de sokszor vagyunk együtt, sokszor alszik nálunk. (13)

- A férjemnek legalább 50\%-ban ki kell vennie a részét, meg segíteni abban, hogy ilyen értelmiségi pályára mehessek. Nekem ez természetes, és nekem nagyon sok házaspár ismerösöm van, ahol ez meg is valósul, az tény, hogy a keresetükben van egy óriási nagy különbség. A nö mindig a harmadát keresi a férjének, de a házimunka az fele-fele, meg a munka is ugyanannyi. (09)

A családról alkotott elképzelések szintén fontos szerepet játszanak, és mindenki, aki ehhez a csoporthoz sorolódik, család alapítását tervezi, a boldogulás feltételének tartja a kiegyensúlyozott családi életet, de nem téveszti szem elől, hogy vannak családon kívüli tervei is. Ez abban mutatkozott meg, hogy az emancipáltnak nevezett személyek esetében mind a család, mind a karrier tervezésénél megfogalmazódott, hogy áldozatokat kell hozni mindkét oldalon: tehát olyan munkát kell vállalni, ami mellett megoldható a család, és annyi gyereket kell szülni, ahány mellett a kitűzött célok megvalósíthatóak. A családi- és karriertervek megvalósításához elengedhetetlennek tartják a leendő férj együttműködését is.

- Én kettö gyereket mindenképpen szeretnék, de azt hogy hogyan és mikor, meg, hogy hány év legyen közöttük, meg hogy esetleg hármat, ezek mind attól függnek, hogy mi lesz a szakmában. (06)

- Kettó-három mondjuk attól függ, hogy az anyagiak meg ilyesmik, de kettóben gondolkodom egyenlöre, de hármat is szívesen. De én abban is biztos vagyok, a londoni példa alapján, és remélem ez anyagilag megengedhetỏ lesz, hogy mindenképp szeretnék segítséget. (09)

- Én nagyon szeretem a munkámat, én nem tudnám elképzelni, hogy háziasszony legyek öt gyerekkel, de azt viszont tudom, hogy egy sem jó, ahogy én éltem testvér nélkül, tehát a kettô. (16)

Ebben a csoportban rajzolódott ki legmarkánsabban az a vélemény, hogy a szocializmus női emancipációjának alapvető problémája: nem azokat a célokat tűzte ki, ami a nőket valóban egyenlővé tehette volna, illetve a megvalósítás sem járt együtt a nők valós egyenjogúsításával.

- Szerintem a kommunizmusban nem volt egyenjogúság, mert az volt a kép, hogy a nö is annyit dolgozik, mint a férfi, és aztán hazamegy és ellátja a háztartást - az nem egyenjogúság. (11) 
- Ez azért volt disznóság, amennyiben valóban meghirdették a nöi egyenjogúságot, ez azt jelentette, hogy a nö is dolgozhatott napi nyolc órát, de valóban kevesebb fizetést kapott, tehát tényleg mocsok húzás volt, és valószínüleg az is igaz volt, hogy alacsonyabb pozícióba vették be a nöket, az igazgató például egy iskolában férfi volt, ehhez képest az egész tanári kar nö volt, és ez tény. (20)

A rendszerváltás utáni időszakról ez a csoport úgy vélekedett, hogy ez a korszak több lehetőséget hozott a nőknek, beleértve a lehetőségekbe azt is, hogy a nők, ha ezt szeretnék választani, mint anyák, háztartásbeliek élhetik le életüket.

- Nemcsak a fiúknak, a lányok elött is most az a modell, ez az eszméletlen hajtás, hogy most még elérni valamilyen életszínvonalat, meg nem is értem, most kell jól helyezkedni, meg jól teperni, hogy aztán majd egy kicsit lazíthassál, és aztán majd beállhassál egy jó életszínvonalra. (06)

- Hogy mennyire jó az, hogy az ember karriert csinál és nem otthon van, ezt baromi nehéz megmondani, mert én már csak a saját eszemmel tudok gondolkodni, és én úgy nevelkedtem, hogy nekem valamit ki kell hoznom magamból, nekem meg kell mondanom, hogy ki vagyok, hogy nekem is valamit le kell tennem az asztalra. (16)

A nemi szerepekkel kapcsolatos válaszok igen színes képet mutatnak, hiszen az emancipált csoport tagjainál is elhangzottak erőteljesen esszencialista megjegyzések, de az ebbe a csoportba sorolt személyektől származtak azok a magyarázatok is, melyek szerint a társadalom kondicionálta a mai nemi szerepeket, vagy hogy történeti okokban kell keresni a különbségek eredetét.

- Az biztos, hogy évszázados vagy évezredes az a tradició, hogy a férfi tartja el a családot, ö az, aki a hátán viszi a többi családtagot, ebben biztos vagyok, hogy ez nagyon fontos, szerintem ez még életben van. (16)

- Szerintem nagyban az van, hogy a hagyományos felfogásban az anya otthon van, és a férj a kenyérkereső, és ezért neki nagyobb beleszólása van a dolgokba, és szerintem ez még mindig nagyon érzödik. (15)

\section{KONFLIKTUSOS CSOPORTOK}

Az ambivalencia, amelyet egyrészt a női egyenjogúsággal kapcsolatos intézkedések hoztak a második világháborút követő és máig tartó évtizedek során, illetve amely döntően meghatározta a mintában szereplő személyeknek nyújtott szülői modellt, az általam vizsgált csoportban is megjelent. A megkérdezett személyek egy jelentős csoportját (7 személy), mint említettem, nem lehetett a fenti egydimenziós kategorizáció szerint besorolni, annak ellenére, hogy minden interjúalany explicit és egyértelmủ utalásokat tett arra vonatkozóan, hogy magát tradicionális vagy emancipált női szerepben szeretné-e látni a jelenre vonatkozó önjellemzésekben és a jövőre kialakított elvárásaiban. A harmonikus csoportok egyértelműen elkülönít- 
hetők voltak a vélemények hasonlósága alapján az érintett témák során, ezzel szemben a konfliktusos csoportokat az jellemezte, hogy bizonyos témák tárgyalásakor az elköteleződés egyik vagy másik értékrend mellett világos és explicit volt, máshol ellentétes és ezzel inkonzisztens véleményeket kaptunk.

\section{A konfliktusos-konzervatív csoport}

Négy személyt soroltam ebbe a csoportba, közülük kettő hagyta félbe az egyetemet, és kezdett más tanulmányokba, kettőjüknek tanári/tanítói végzettsége van, és egyiküknek sincsen állandó partnere, amelyek mind hozzájárulhatnak ahhoz, hogy nem érzik azt a fajta konkrét késztetést, amely az előző két csoportnál megtalálható volt, hogy kialakítsanak egy egységes és következetes képet a múlt rekonstruálásában és életcéljaik kialakításában.

Konfliktusos-konzervatívok közé soroltam azokat a személyeket, akik explicit módon állást foglalnak a tradicionális értékrend mellett, akik a női emancipációt nyíltan elítélik, a nő szerepkörét a férfiénél alacsonyabb rendűnek tekintik, akik a családi szerepekben nem törekednek egyenlőségre, és bár elvárják, hogy a férfi nyújtson némi segítséget a családban és a háztartásban, ezt nem azért várják el, mert egyenlőségre törekszenek a kapcsolatban. A legtöbben ugyan rendelkeznek karriertervekkel, vagy már eddig is elmondható, hogy szakmai téren sikereket értek el, ezek azonban belső konfliktust okoznak számukra, mert úgy érzik, ambícióik más szemében elitélendők. Úgy vélik, hogy a család érdekében nem kölcsönös kompromisszumokat, hanem a munka, a karrier terén kell áldozatokat hozni. Az áldozatok meghozatalát azonban ma még korainak tartanák, a döntést a jövőbe tolják.

A konfliktusos-konzervatív csoport esetében a tudatosan vállalt, explicit módon megfogalmazott állásfoglalások mellett ellentmondásos életút terve rajzolódik ki, amelyben többnyire a családról alkotott tradicionális értékrend mellett egy szakmai karrierterv is áll, amit azonban a megkérdezettek mind önmaguk, mind mások esetében elítélnek.

- Én is akarok dolgozni, én sem akarok egész nap otthon ülni, mindenféleképpen akarok valami produktívat csinálni, de szerintem, akkor is egy nönek foglalkoznia kell a családdal, foglalkoznia kell a férjével, kaját kell föznie, és ez a normális menete az életnek, mindig is ez volt. (10)

A családi háttér jellemzésekor nem tartották jónak, ha az anya nem tudott a családjával lenni, bár elhangzottak negatív vélemények az anyát ért karrierkudarcokkal kapcsolatban is. Itt erősen érződnek a családi háttérben mutatkozó egyéni különbségek a kis mintaszám miatt, így csak egy-egy példát kaphattunk a különböző esetekre. A modellek szempontjából sem különült el ez a csoport a konzervatív csoporttól: modelljeik főként a családtagok közül kerültek ki.

Ezt a csoportot párkapcsolat témája köti leginkább a konzervatívokhoz. Egyértelműen az kitűnt a beszélgetésekből, hogy nem törekednek egyenlő viszonyra 
partnerükkel, a férfinak való alárendeltséget a maguk vonatkozásában elfogadhatónak tekintik, sőt, egyesek az egyenlőtlen viszonyt a jó kapcsolat feltételének tekintik.

- Szeretem azt, hogyha másodlagos szerepben vagyok. (07)

- Egy olyan ember nekem nem kell, ahol én vezetó egyéniség vagyok, tehát ha én kérdezek, akkor tudjon nekem valaki válaszolni, és ne az legyen, hogy nekem kelljen állandóan dönteni. (10)

Emellett ha el is várják, hogy a partner részt vegyen az otthon végzendő munkában, csak praktikus okokból teszik. Az anyagi függőséget egyetlen, ebbe a csoportba sorolt megkérdezett sem tekintette problematikusnak.

- Nekem az az igazi férfi, aki mellett én nönek tudom érezni magam. Engem most például eltart a barátom, és engem ez egyáltalán nem zavar. Szóval nincsenek bennem ambiciók, hogy megállok a lábamon, hogy önálló nö vagyok. (...) Én házasságellenes is voltam, a gyerekekkel sose tudtam bánni, most sem tudok. (07)

A családról, gyerekvállalásról elhangzottak a párkapcsolattal ellentétben már nem minden esetben hasonlítanak a konzervatív csoportra, bár itt is általános a vélemény, hogy a családi munkamegosztást, főként a gyereknevelést hagyományos módon kell kialakítani férfi és nő között.

- Nekem az a kép, ami mondjuk egy konzervatív kép, hogy a férfi dolgozik, és a nö otthon van, és foglalkozik a háztartással, az feltétel. Tehát én nem tudnék úgy családot alkotni, hogy én dolgozom is, meg gyereket is nevelek. Én otthon vagyok, és a férfi dolgozik. (10)

Ide soroltam azt a válaszolót, aki egyáltalán nem tervez gyereket, de a többiekre is az volt jellemző, hogy a gyerekvállalást későbbre időzítenék a kapcsolat vagy a partner éretlensége, a partner hiánya vagy az élethelyzet kialakulatlansága miatt.

- Lehet, hogy egyszer majd meguáltozik az elképzelésem, és majd eröt vesz rajtam az anyai ösztön és szülök egy gyereket, de most nem tudom elképzelni. (07)

Inkább csak kevesebb gyereket szeretnének, egyet vagy kettőt, anyagi jellegü vagy más külső akadályokra hivatkozva.

- Mindig lelkes voltam, hogy sok gyereket szeretnék, most azt gondolom, hogy nem szeretnék sok gyereket, szóval kettót, talán hármat, pont a felelösség miatt. Meg akarom nekik adni mindazt, amiröl azt gondolom, hogy tölem tudnak megkapni, másrészt biztosítani akarom valahogy a jövójüiket, ami most egy nagy ciki a világnak ezen a részén, én például azt látom, hogy az én szüleim teljesen beleöregedtek abba, hogy nem tudnak nekünk lakást szerezni, ez nagyon megviselte óket, és ezt nem akarom átélni. (12) 
A családi és szakmai tervek egyidejủ megvalósításáról nem rendelkeztek határozott elképzelésekkel. Volt, aki egyértelmüen problémának, sőt, a harmonikus csoportokhoz képest súlyosabb problémának is tekintette, de többen úgy beszéltek erről, hogy majd akkor, lehetőleg a távolabbi jövőben föl fogják adni a karrierterveiket.

- Ettöl egy kicsit meg is vagyok rettenve, az biztos, hogy amíg kicsik lesznek a gyerekeim, addig otthon leszek, ebben biztos, hogy a mamám mintája van bennem. És akkor azt gondolom, hogy ha rá leszek kényszeritve, hogy pénzt keressek, akkor is inkább magántanítványokat fogok vállalni, tehát nyelvet tanítani gyerekeknek vagy korrepetálni, vagy ilyesmi. Mert azért tényleg azt látom, hogyha valaki rendesen dolgozik egy iskolában, akkor hiába szabad a délutánod - ez egyrészt nem igaz, mert ha lelkiismeretesen csinálod, akkor nagyon sokat készülsz másnapra, még akkor is, ha már száz éve csinálod -, meg fáradt az ember, meg úgy vettem észre, hogy annyira nehéz egy iskolában eltöltött délelött után még adni. És az ember a gyerekeinek alapvetöen adni kell, hogy tudjon, mert persze kap is egy csomó mindent, de adni muszáj, és ott nincsen lamenta, ott nem mondhatod azt, hogy fáradt vagy, ott teljesíteni kell. Ószintén szólva nem tudom, hogy hogy fogom csinálni, ez a durva benne. Ilyen idósebb tanároktól szoktam hallani kicsit lelkifurdalással, hogy ök igenis a saját gyerekektöl vették el, nekik nem tudtak annyit adni. (12)

- Ameddig csak lehet, szeretnék otthon maradni a gyerekekkel, de talán én úgy tudnám elképzelni, hogy inkább az ilyen háztartási munkákat megcsinálnám, de azt nem, hogy mindent én csináljak, azt azért nem, és valamennyire, amit mondtam, hogy fordítani, vagy valami kis itthoni munkákat szívesen el tudnám képzelni magamnak a gyerekek mellett. És akkor mégis a gyerekekkel is vagyok, meg pénzt is keresek, valami ilyet tudnék elképzelni magamnak, ilyen álmaim vannak. (18)

Szakmai ambíciókról elsősorban a konkrét, közeljövőre vonatkozó tervek kapcsán esett szó, egyik személy sem beszélt hosszabb távú szakmai célokról. Általánosságban viszont mindenki elitélte a karrierista nőt, úgy vélték, a magas, vezető beosztás a nőiesség elvesztésével jár.

- Nekem valahogy meggyözödésem, tisztelet a kivételnek, hogy azért nö vezetö pozícióba ne nagyon császkáljon, én például nem szeretném, ha nöi fönökeim lennének, bármilyen munkakörben is dolgoznék, hogyha egy nö nagyon magasra feljut, vezetö pozícióba, akkor a személyisége annyira átalakul, mert neki mindkét helyen helyt kell állni, mert neki fel kell venni a versenyt a férfiakkal, neki el kell fogadtatnia magát a férfiakkal, annyi görcs lesz benne, hogy az valahol csak rosszul fog elsülni. (07)

Ebből következően a szocializmus nőképét is negatívan ítélték meg, mégpedig a harmonikus konzervatív csoporthoz hasonlóan az a vélemény tükröződik a válaszokból, hogy a szocializmus női egyenjogúsága tönkretette a nő és férfi között hagyományosan létező szerepfelosztást, a nőkben tönkretette a nőiességet. 
- Az, hogy minden szempontból egyenjogúság van, azzal nem teljesen értek egyet, mert más egy nö, meg más egy férfi, ilyen szempontból tehát, hogy teljesen egyforma egy férfi és egy nö, azzal nem értek egyet, manapság van egy-két hülye fanatikus nö, aki az egyenjogúságáért harcol, de az összességében nem tetszik. Az, hogy a nö is egy ember, az oké, de az, hogy a nö is menjen le a bányába dolgozni, ilyen szempontból ne legyünk egyenjogúak. Nem tudom, hogy hol lehetne meghúzni a határt. (18)

A rendszerváltással kapcsolatban ettől a csoporttól származott az a kritika, miszerint nőiességüket elvesztő karrierista nők termelődtek ki ebben az időszakban.

- Ma már nagyon elterjedt a világban, hogy a nö is ilyen üzletasszony, meg a nö is csinál karriert, azt gondolom, hogy ez nem egészséges, érdekes megnézni nyugaton ezeket az üzletasszonyokat, akik 40 évesen totál kiüresedve állnak, és szerintem mindegyik rájön, hogy valamit totál elrontott, mindenük megvan, házuk, Mercedes-ük, van eszük, ritka esetben van egy stabil kapcsolatuk, de ez nagyon ritka, és általában nincsenek gyerekeik, és mindent elértek, szuperül megy a vállalatuk, de azt gondolom, hogy egy nönek ez baromi kevés. (12)

A nők és férfiak közötti különbségekre, a konzervatív meggyőződés értelmében igen esszencialista véleményeket soroltak fel.

- Eredetileg az ősközösségben a férfiak dolga volt az, hogy legyen kaja, vadászni kellett, tehát szerintem ezért a férfiakban genetikailag determinált dolog lehet, hogy egyszerre egy dologra tudnak koncentrálni, és ettöl van ez a befelé figyelés. A nöknek egyszerre sokfelé kell koncentrálniuk, mert nekik az ösidöben az volt a feladatuk, hogy a nyolcezer gyerekre figyeljenek, közben magokat gyüjtögessenek, meg lepényt süssenek, és ma ez ugyanígy van, egy nönek egyszerre több terepen kell megállnia a helyét, és szerintem erre képesek is a nók. És nem is haragszom a férfiakra, hogy nem képesek rá. (12)

\section{Konfliktusos-emancipált személyek}

Csupán három személyt soroltam ebbe a csoportba, akik egymástól sok szempontból eléggé eltérőek családi hátterüket, végzettségüket tekintve, egyikük második diplomáját szerzi, a másik személy főiskolát végzett, s jelenleg egy állami munkahelyen dolgozik, harmadikuk pedig jelenleg a bölcsészkarra jár. Eltérő partnerkapcsolataik kialakultsága is, egyikük férjnél van, de még nincsen gyermeke, a másik kettőnek pedig nincsen állandó partnere.

E kategóriába tartoznak azok a személyek, akiknek határozott elképzeléseik vannak arról, hogy karrier terén hova szeretnének vagy hova lehet eljutni, mindezt belső motívumok által vezérelve szeretnék elérni, párkapcsolataikban egalitáriánus viszonyt igyekeznek kialakítani, a női emancipációt elfogadják és értékelik, de akiknek a családról és az anyaszerepről tradicionális elképzeléseik vannak, melyeket nem tartanak összeegyeztethetőnek a karriertervekkel. Ennél a csoportnál a család és a karrier dilemmája rendkívül kiélezett volt. 
A konfliktusos-emancipált csoport legfőbb jellemzője, hogy bár szeretné egy emancipált nő életvitelét követni, ezzel nem tud megbékélni, mert túl erősen élnek benne a nőkkel szembeni tradicionális elvárások. A családi modellek ambivalens üzenetei több esetben is előfordultak a megkérdezett személyeknél. Az anya ugyan többnyire dolgozott, több esetben kifejezett szakmai sikereket ért el, azonban mindezt úgy élte meg, mint egy az eredeti szándékaitól és vágyaitól eltérő életpályát, illetve úgy enyhített ezen az ellentéten, hogy igyekezett a családon belül megőrizni a tradicionális szerepfelosztást.

- Az anyám úgy szerette volna leélni az életét, hogy ha lehet, hogy szül hat gyereket, ezt persze nyilván a lehetóségekhez képest, ó semmi más, mint családanya szeretett volna lenni, meg háztartást vezetni. Nem tanulhatott, mert nem volt pénzük, 18 évesen el kellett menni dolgozni, meg azóta hát végig kellett dolgoznia az életét, tehát a gyerek volt az egyetlenegy fogódzó az életében, és mivel én egyke lettem, ezért én voltam egyedül, akiben mindazt, amit szeretett volna, kiteljesithette. (01)

A konfliktusos-emancipált csoport esetében a párkapcsolat kérdésében kiütközik az ambivalencia: a megkérdezetteknek egyszerre van igényük arra, hogy egalitáriánus viszonyokat alakítsanak ki, de egyúttal arra is, hogy jelen legyen a kapcsolatban egy tradicionálisabb férfi-nő viszony.

- Az a tudatosabb vágy, hogy egyenlönek kezeljenek, de azért mellette néha szükségem lenne arra, hogy nönek érezzem magam. (01)

A megkérdezettek nem törekednek arra, hogy a családban egyenlően legyen megosztva a munka, elfogadják, sőt helyénvalónak tartják, ha a háztartás a nő feladata.

- Az anyu vezette a háztartást, hát szerintem ez lehet, hogy konzervatív, de végül is én is igy gondolom, hogy egy nönek a feladata a fózés, a mosás, a mosogatás. Az apu néha kiporszívózott, a családban a férfiak egyetértenek abban, hogy maximum a porszívózás férfimunka, egyébként semmi más, de abszolút így gondolom, hogy ez egy nönek a feladata. (04)

A többieknél felmerült az az elvárás, hogy a férfi ne hagyja őket magukra a háztartásban. Náluk is megtalálhatjuk azt az igényt, hogy e téren is kialakuljon valamiféle egyenlőség férfiak és nők között, ebben azonban elfogadnak fokozati különbségeket. A családalapítás, a gyermekvállalás témájának felvetésekor hangzottak el a leginkább tradicionális vélemények, ezen a területen nagyobb hasonlóság mutatkozott a konzervatív, mint az emancipált csoporttal. Elképzeléseik szerint a család a boldogulás kulcsa, amit a nőnek szakmai ambíciói alá kell rendelnie. Ezzel szemben jelen élethelyzetükben nem ezt a képet látják megvalósulni, amit a jövőben szándékoznak „korrigálni”. 
- Szakmailag azt mondhassam, hogy elértem valamit, és onnantól kezdve arra tudjak építeni, és akkor a családom legyen a legfontosabb az életemben. (...) Most azt fogom mondani, hogy a családom a fontosabb, de lehet, hogy amiatt van, mert az is benne van egy jóérzésü nöben, hogy egy nönek az a sorsa, hogy a család a legfontosabb, én remélem, hogy meg fogom találni az egyensúlyt, ahol azért fontosabb persze a család. (01)

- Azt szeretném, hogy elérjek addig valamit, amire így büszke leszek, hogy úgy tudjak családot alapítani, hogy ne az legyen, hogy a semmiböl egyszer csak ott a család, hanem már úgy érezd, hogy te is tettél már valamit. (...) Most már elmúlt az az idö, hogy az legyen a családmodell, hogy nincs munkája, és nem is akar visszamenni, és lesz belöle egy jó kis unatkozó háztartásbeli. Akkor én biztos meghülyülnék. (04)

A csoport tagjai a munka és család közötti feszültséget olyan tervek szövésével próbálják feloldani, amelyek alapján magukat tradicionális szerepkörben képesek látni annak ellenére, hogy egyenlőre nem ebbe az irányba terelik életüket.

- Igazából jó lenne elvégezni a jogi egyetemet, de most olyan terveink vannak, hogy egy év múlva szeretnénk gyereket, mert már lassan a korban vagyunk, meg már anyukám nagyon pedzegeti, hogy jó lenne, ha már nagymama lenne, és akkor nem tudom igazából, hogy a gyerek mellett mit lehet csinálni, mert kétféle lehetöség van, vagy estin végzem vagy levelezön, mind a kettönek megvan a hátulütóje... jó hát végül is meg lehet oldani, csak nem tudom, hogyan. (17)

Szakmai törekvéseik nagyon határozottak és ambiciózusak voltak, tehát a továbbtanulás, a második diploma minden megkérdezett tervében szerepelt, azonban ezeket a terveket nemigen hozták kapcsolatba a családról alkotott aránylag konzervatív képpel.

- Ha az motiválna, hogy mit akarok csinálni, akkor elmennék egy nyelviskolába szépen angolt tanítani, de igazából engem az is motivál, hogy mennyit tudok keresni, és ezzel körülbelül semmit. (...) Meg kellene csinálni egy ilyen közgáz szerü diplomát, egy MBA-t. Ez most még elég kevés embernek van Magyarországon, ha esetleg meg tudnám csinálni, akkor az egy nagyon jó diploma lenne. (04)

A női egyenjogúság kérdésében egyértelműen az emancipált csoporttal egybehangzó véleményt hangoztattak. Tehát a szocialista nőképpel szemben azt hozták fel legfőbb kifogásként, hogy nem valósította meg céljait, míg a rendszerváltással kapcsolatban a lehetőségek megnövekedéséről beszéltek. Mindemellett megjelent az a fajta vélekedés is, hogy a túlzottan karrierista nő képe visszatetsző lehet, tehát ezen a téren is tükröződött némi ellentmondás.

- Nem tudom igazából mi volt elótte, csak azt látom, hogy milyen fiatal nói réteg termelödött ki a rendszerváltás környékén. Van az a sokat keresö, kiskosztümös, közgázt végzett, banki alkalmazott, vezetömenedzser, ilyen iszonyatosan nyomulnak, kökeményen, 
nagyon durván taposva, gyilkolva, szóval egy ilyen elég hányás réteg. Én azt hiszem, hogy nem is nagyon vágynak gyerekre, szóval, akik meglátták azt a lehetöséget, hogy ök karriert tudnak csinálni, és csinálnak is. Elég férfias módon. (01)

- Nem szabad nagyon karrieristának lenni, hogy az ember föladja a családját miatta. Egy férfinak az a célja, hogy életében egyre magasabbra másszon és egyre többet elérjen. Egy nönek ez is fontos, de ugyanakkor, ha már ott a család, akkor azért az az elsö.

A nemek közötti különbségekre vonatkozóan - úgy tűnik - a csoport tagjai férfiak és nők között felfedezik a társadalom által létrehozott különbségeket is a biológiai adottságok mellett.

- Csak egy anya szüli a gyereket, itt sincs munkamegosztás, és csak más az, hogy valaki anya vagy apa, szerintem érzelmileg is más. (17)

\section{KÖVETKEZTETÉSEK}

A négy csoport kirajzolódása azt mutatja, hogy a társadalom nőkre vonatkozó ambivalenciáit ugyan minden személy valós problémának érzékelte, de ez az ambivalencia harmonikusan vagy konfliktusokkal terhelve beépíthető az életútjukba. A konzervatív értékrendet vallók csoportjának minden tagja úgy vélekedett, hogy az általa képviselt értékrend a társadalomban csak marginálisan jelenik meg, mégis a megkérdezettek közel fele a konzervatív felfogás követőjének tartotta magát. Az emancipált nézeteket vallók is pozitív változásnak tartották, hogy ma a nők dönthetnek úgy, hogy kizárólag gyermekeiknek szentelik magukat, és nem kényszerülnek munkavállalásra. Egyértelmű tehát, hogy a társadalomban a tradicionális nemi szerepfelosztás irányában történt bizonyos elmozdulás. Ezzel együtt azonban olyan nagyfokú változás következett be a szakmai érvényesülés lehetőségeiben - a nők számára is -, hogy a megkérdezettek ezt a tendenciát tekintik a változás domináns irányának.

Az emancipált és a konzervatív csoportokba sorolt személyek nem abszolút értelemben vett értékeket képviselnek, hanem azoknak korántsem letisztult, ambivalenciákkal terhelt és a mai magyar társadalomban elképzelhető formáit. Az ambivalenciára utaló különböző családi modellek mellett válaszolóim értékrendjében együtt szerepelnek a női munkavállalással szembeni ellenérzések, de egyúttal a kétkeresős családmodell internalizációja és a családpolitikai intézkedések következményeként újra elterjedt hagyományos értékrend megbecsülése is. Közülük az utóbbi a rendszerváltással még nagyobb méreteket öltött, hiszen ehhez hozzájárult az is, hogy a női emancipáció a szocialista hatalomnak felülről a társadalomra erőltetett jelenségévé degradálódott, emellett a konzervatív ideológia az élet más területein is népszerűbbé vált. 
A két eltérő értékrend mentén történő választás több szempontra vezethető vissza. Az életkor, az élethelyzet és a társadalmi-politikai kontextus mind hozzájárulhatott a kapott eredményekhez. Az életkor azt sugallja, hogy a megkérdezettek a felnőtt élet kezdetén állnak, amikor már elkerülhetetlen, hogy döntéseket hozzanak szakmai érvényesülésüket és a leendő család kialakítását illetően. Élethelyzetük szempontjából a megkérdezettek olyan szocioökonómiai szempontból speciális, értelmiségi csoport tagjai, akik megengedhették maguknak, illetve fontosnak tartották a felsőoktatási intézményben való tanulást, akiknek életcéljai közé tartozott az anyagi és társadalmi elismertégbeli magas színvonal. A társadalmi-politikai kontextus személyes aspektusának tekinthető, hogy interjúalanyaim a késő szocializmus éveiben voltak kiskorúak; szüleik lehetőségeit, érvényesülését és családi szerepét is meghatározta ez a kor és a szocializmus intézményrendszere. Másrészt abból a szempontból is hatott a politikai kontextus, hogy a megkérdezettek a rendszerváltozás évei után váltak felnőtté, így saját életükre vonatkozó döntéseiket már egy új világban hozhatták meg. Ebben a világban feltűnt egy nosztalgikus tendencia a tradicionális társadalmi szerepek iránt, egyúttal megszűntek bizonyos korlátok, mind a nők, mind a férfiak érvényesülésének lehetőségei kiszélesedtek.

Mivel sokan még nem kerültek konkrét választások elé sem a magánéleti, sem a szakmai szférában, többször találkozunk azzal, hogy a kutatás szereplői egy alaposan át nem gondolt képet lebegtetnek maguk előtt arról, hogyan múködik egy család, hogyan lehet érvényesülni az életben. Nincsenek a társadalomban stabilan kialakított képek nőkről és férfiakról, mégis mindenki úgy érzi, hogy vannak átvehető panelek, vannak olyan minták, melyeket követni lehet, és az értékek kavalkádjában akkor találhat az ember fogódzót, ha valamely értékrend mellett foglal állást. A megkérdezettek közel fele a hagyományos szerepkörre tart igényt. E csoportok tagjai egyetlen egyszer sem említették az anyaszerep felértékelődésével kapcsolatos távolabbi összefüggéseket, amelyek a társadalmi változásokhoz köthetőek. Nem merült fel, hogy a hagyományos értékrend elterjedésének nemcsak a családi stabilitás növekedése lehet az áldásos következménye, hanem a nők visszaszorítása a privát szférába, illetve a nemek között valamilyen szinten megvalósult egyenjogúság visszabillenése a férfitársadalom javára, amelynek következményei kiterjednének a társas élet minden területére, így a mindenkori férfi-nő kapcsolatra is. Nem csoda, hogy mindezt nem tudja áttekinteni ez a kis, általam kiemelt csoport, hiszen nem számol ezzel a szélesebben vett társadalom sem. Az új helyzetekben szükséges érvényesüléshez hiányoztak az előző generációktól származó, használható modellek (NEMÉNYI, 1999), de nem lehetett segítségükre a nőket leginkább sztereotípiákon keresztül bemutató média sem. A női identitások, női szerepek életutakon keresztül történő megismerése talán hozzájárulhat ahhoz, hogy a nőkre vonatkozó statisztikáknál személyközelibb, a sztereotípiáknál pontosabb képet kapjunk arról, mit jelent nőnek lenni ma Magyarországon.

A vizsgálat puszta eredményeinek ismertetése mellett a kutatás remélhetőleg rávilágított arra, hogy a társadalmat, jelen esetben főként a társadalom nő tagjait érintő jelenségek megközelíthetők a nemek szociális konstrukciójának perspektívájából is, amely egyszerre keresi a személy helyét a társadalomban, illetve a társadalom helyét a személy életében. 


\section{IRODALOM}

Adamik, M. (1993) Feminism and Hungary. In Mueller, M., Funk, N. (eds) Gender Politics and Post-Communism. Routledge, New York-London, 207-212.

Butler, J. (1993) Bodies that Matter. Routledge, New York-London

Corrin, C. (1992) Superwomen and the Double Burden - Women's Experience of Change in Central and Eastern Europe and the Former Soviet Union. Scarlet Press, London, 236-255.

EInHorn, B. (1993) The 'Women Question': The Legacy of State Socialism. In Einrhorn, B. (ed.) Cindarella Goes to Market. Verso, London-New York, 17-38.

FERGE Zs. (1985) Biológiukum és nemek közötti egyenlőség. In Koncz K. (szerk.) Nók és férfiak - Hiedelmek és tények. MNOT-Kossuth Kiadó, Budapest, 68-92.

KonCz K. (1994) Nők a rendszerváltás folyamatában. In Hadas M. (szerk.) Férfiuralom. Replika Kör, Budapest, 209-221.

LAQueur, T. (1990) Making Sex: Body and Gender from the Greeks to Freud. Harvard University Press, Cambridge

LÁszló J. (1998) Identitás és narratívum. In László J. (szerk.) Szerep, forgatókönyv, narratívum. Scientia Humana, Budapest, 137-145.

Marody, M. (1993) Why I am not a Feminist: Some Remarks on the Problem of Gender Identity in the United States and Poland. Social Research, 60/4, 853-864.

NAGy B. (1997) Karrier női módra. In Lévai K., Tóth I. Gy. (szerk.) Szerepráltozások: Jelentés a nők helyzetéröl. Tárki-Munkaügyi Minisztérium, Budapest

Neményi M. (1994) Miért nincs Magyarországon nőmozgalom? In Hadas M. (szerk.) Férfiuralom. Replika Kör, Budapest, 235-245.

NemÉnYi M. (1999) Csoportkép nőkkel. Új Mandátum, Budapest

NemÉnyi M., Tóth O. (1998) A nók társadalmi szerepének változásai az ezredfordulón. Nemzeti Stratégiai Kutatások, MTA, Budapest

NiCHOLSON, L. (1994) Interpreting Gender. Signs, 3, 79-105.

PONGRÁCZ TiborNé (1994) Változások a magyar családban. Info Társadalomtudomány, 30, $13-18$.

Pongrácz Tiborné, S. MOlnáR E. (1997) A gyermekvállalási magatartás alakulása. In Lévai K., Tóth I. Gy. (szerk.) Szerepuáltozások - Jelentés a nỏk helyzetéröl. TÁRKI-Munkaügyi Minisztérium, Budapest

SÁNDORNÉ DR. HORVÁTH E. (1986) A gyestôl a gyedig. MNOT-Kossuth Kiadó, Budapest

SChiebinger, L. (1991) More Than Skin Deep: The Scientific Search for Sexual Difference. In Schiebinger, L. (ed.) The Mind Has No Sex? Women in the Origins of Modern Science. Harvard University Press, Cambridge, 189-213.

ScOTT, J. (1988) Gender and the Politics of History. Columbia University Press, New York, 2850.

Tiefer, L. (1995) Sex Is Not a Natural Act Boulder. Westview Press, San Francisco

Tóth O. (1993) No Envy, No Pity. In Funk, N., Mueller, M. (eds) Gender Politics and PostCommunism Routledge. New York-London, 213-223.

Weitz, Rose (ed.) (1998) The Politics of Women's Bodies. Oxford University Press, OxfordNew York, 12-24. 
FAMILY AND/OR CAREER:

THE SOCIAL CONSTRUCTION OF THE LIFE-ROUTES OF YOUNG WOMEN

\author{
KENDE, ANNA
}

The article summarizes the results of an empirical study conducted using the method of indepth interviews. Social expectations, as well as personal experiences of gender and femininity are analysed based on the life-routes of twenty young women. Social constructionist theories, providing the theoretical background of the study, enable us to understand the concept of femininity beyond biological differences, as it is embedded in the body, society, and personal experiences. From the content analysis of the interviews we see that part of the group identifies with an egalitarian viewpoint, while others identify with a conservative one in the context of the contradictory social expectations toward gender roles. Furthermore, we can perceive whether the chosen value system in incorporated in a harmonious or conflituous way into the life-route. The characterisation of the four groups that were gained as a result of the categorisation contributes to the understanding of the effects of societal changes on personal lives in the area of gender roles

Key words: gender identity, social construction, egalitarian/conservative value system, life-route interview 